\title{
Lipotoxicity, neuroinflammation, glial cells and oestrogenic compounds
}

\author{
Oscar Hidalgo-Lanussa ${ }^{1}$ | Eliana Baez-Jurado ${ }^{1}$ | Valentina Echeverria ${ }^{2,3}$ | \\ Ghulam Md Ashraf $^{4}$ | Amirhossein Sahebkar ${ }^{5,6,7}$ | Luis Miguel Garcia-Segura ${ }^{8,9}$ | \\ Roberto C. Melcangi ${ }^{10}$ (D) | George E. Barreto ${ }^{1,11}$
}

${ }^{1}$ Departamento de Nutrición y Bioquímica, Facultad de Ciencias, Pontificia Universidad Javeriana, Bogotá, Colombia

${ }^{2}$ Facultad de Ciencias de la

Salud, Universidad San Sebastián,

Concepción, Chile

${ }^{3}$ Bay Pines VA Healthcare System, Research and Development, Bay Pines, FL, USA

${ }^{4}$ King Fahd Medical Research Center, King Abdulaziz University, Jeddah, Saudi Arabia

${ }^{5}$ Neurogenic Inflammation Research Center, Mashhad University of Medical Sciences, Mashhad, Iran

${ }^{6}$ Biotechnology Research Center, Pharmaceutical Technology Institute, Mashhad University of Medical Sciences, Mashhad, Iran

${ }^{7}$ School of Pharmacy, Mashhad University of Medical Sciences, Mashhad, Iran

${ }^{8}$ Instituto Cajal, CSIC, Madrid, Spain

${ }^{9}$ Centro de Investigación Biomédica en Red Fragilidad y Envejecimiento Saludable (CIBERFES), Instituto de Salud Carlos III, Madrid, Spain

${ }^{10}$ Dipartimento di Scienze Farmacologiche e Biomolecolari, Università degli Studi di

Milano, Milano, Italy

${ }^{11}$ Department of Biological

Sciences, University of Limerick, Limerick, Ireland

\section{Correspondence}

George E. Barreto, Department of Biological Sciences, University of Limerick, Limerick, Ireland.

Email: gesbarreto@gmail.com; George. Barreto@ul.ie

\begin{abstract}
The high concentrations of free fatty acids as a consequence of obesity and being overweight have become risk factors for the development of different diseases, including neurodegenerative ailments. Free fatty acids are strongly related to inflammatory events, causing cellular and tissue alterations in the brain, including cell death, deficits in neurogenesis and gliogenesis, and cognitive decline. It has been reported that people with a high body mass index have a higher risk of suffering from Alzheimer's disease. Hormones such as oestradiol not only have beneficial effects on brain tissue, but also exert some adverse effects on peripheral tissues, including the ovary and breast. For this reason, some studies have evaluated the protective effect of oestrogen receptor (ER) agonists with more specific tissue activities, such as the neuroactive steroid tibolone. Activation of ERs positively affects the expression of pro-survival factors and cell signalling pathways, thus promoting cell survival. This review aims to discuss the relationship between lipotoxicity and the development of neurodegenerative diseases. We also elaborate on the cellular and molecular mechanisms involved in neuroprotection induced by oestrogens.
\end{abstract}

\section{KEYWORDS}

lipotoxicity, microglia, neurodegenerative diseases, neurosteroids, obesity, oestrogens, oestrogens

\section{1 | INTRODUCTION}

Obesity and the consumption of a high-fat diet significantly increase the levels of free fatty acids (FAs) in plasma, as well as the 
public health problems. ${ }^{2}$ A diet rich in simple sugars and saturated FAs reduces the expression of brain-derived neurotrophic factor (BDNF) and low BDNF levels are associated with insulin resistance and metabolic syndrome. ${ }^{3}$ The fat ingested with food has a dual function in the body. First, the energetic function of ingested fat is associated with the regulation of gene expression that affects the metabolism of lipids, carbohydrates and proteins, as well as cell growth and differentiation. ${ }^{4}$ Second, FAs interact with the genome via different mechanisms, including: (i) alteration of various transcription factors such as proliferator-activated receptor, insulin and liver $X$ receptor, hepatocyte nuclear factor 4 , nuclear factor-kappa $\mathrm{B}(\mathrm{NF}-\mathrm{kB})$ and sterol regulatory element-binding proteins; (ii) regulation of enzymes such as cyclooxygenase, protein kinase C, superoxide dismutase and catalase; and (iii) changes in the structure of cell membrane, affecting G protein-coupled or tyrosine kinase receptors. ${ }^{5}$

Metabolic alterations modify the correct functioning of the central nervous system (CNS) by changing the neuronal and glial environment. ${ }^{6}$ Also, the progression of CNS diseases is a consequence of the occurrence of exacerbated inflammatory processes that lead to continuous and systematic deterioration of brain tissues. ${ }^{7}$ Recent studies have suggested that people with obesity are more prone to develop cognitive pathologies such as Alzheimer's disease (AD), amongst others, ${ }^{8}$ leading to the generation of a large number of inflammatory processes as a consequence of the excess of free FAs. ${ }^{9-11}$

Some decades ago, it was possible to characterise the cellular components responsible for the regulation and control of inflammation in the nervous system. ${ }^{12}$ The glial component primarily comprises astrocytes and microglia, which are the main cells that are responsible for the regulation of inflammation. ${ }^{13}$ Acute activation of glia modulates the neuroinflammatory response in a protective manner. By contrast, chronic glial activation promotes neurodegeneration via the secretion of inflammatory factors involved in neuronal loss. ${ }^{14}$ The regulatory mechanism is an extremely complex process determined by the transduction of inflammatory-type signals mediated by cytokines and chemokines. ${ }^{15}$ Despite the large body of information available concerning the inflammatory mechanisms, it is not yet completely clear how the regulation of inflammation is carried out and how it can be altered in pathological events. ${ }^{16}$ However, previous studies support the idea that modulation of exacerbated inflammatory processes may hold therapeutic potential for many diseases of the nervous system. Inflammation can be regulated by the elimination and detoxification of neurotransmitters such as glutamate and intracellular messengers by the glial cells. These cells are able to regulate glutamate levels under physiological and pathological conditions, contributing to oxidative stress reduction, synaptic homeostatic maintenance and the regulation of inflammatory signals. ${ }^{17,18}$ In this regard, neuroactive steroids could play a critical role in the regulation of inflammatory processes in a pathological context, mainly by affecting the immunomodulatory function of astrocytes and microglia. Oestrogens can positively regulate the expression of inflammatory mediators (cytokines and chemokines) produced by microglia and other glial cells that are involved in neuroinflammation and neurodegeneration. ${ }^{19}$

It is clear that the brain is a steroidogenic tissue ${ }^{20}$ and a target of endogenous and exogenous steroids. It is noteworthy that neuroactive steroids are steroids that originate from peripheral glands (ie, steroid hormones), which have effects on nervous tissue, whereas neurosteroids are those directly synthesised in the nervous system. It has been reported that treatment with oestradiol regulates the expression of endoplasmic reticulum stress proteins, ${ }^{11,21,22}$ protects mitochondria, ${ }^{22-25}$ and regulates the expression and activation of membrane oestrogen receptors (ERs), in addition to reducing the activity of proapoptotic proteases such as calpain and caspase- 3 in glial cells under different metabolic challenges. ${ }^{26}$ Although palmitic acid may induce toxicity in glial cells ${ }^{27,28}$ and oestrogenic compounds attenuate palmitic acid-induced neuroinflammation, ${ }^{29-32}$ the signalling mechanisms involved in these oestrogenic actions are not fully explored and deserve further studies. This review highlights the inflammatory processes evoked by free FAs in glial cells. We also discuss the mechanisms of action of neuroactive steroids in the regulation of inflammation in glial cells, as well as the therapeutic options that attenuate degeneration in the nervous system caused by glial reactivity.

\section{I METABOLISM OF FATTY ACIDS AND CELLULAR MECHANISMS DURING INJURY}

FAs are an essential source of energy and ATP for the maintenance of cellular functions. ${ }^{33}$ Excess FAs, glucose and other nutrients can be efficiently stored as adipose tissue. ${ }^{34}$ Triglycerides provide more than twice the energy in the form of ATP compared to carbohydrates or proteins ${ }^{35}$ because their catabolism generates more reducing equivalents $\left(\mathrm{FADH}_{2}\right.$ and $\left.\mathrm{NADH}_{2}\right)$ and acetyl-CoA during $\beta$-oxidation in the mitochondria.

FAs are fundamental for cellular functioning because they are used as energy sources via $\beta$-oxidation under strict enzymatic control at the mitochondrial and peroxisomal levels. ${ }^{36}$ It has been reported that FAs can be cytotoxic when the regulation of their metabolism is not adequate, with characteristic physiopathological consequences such as the induction of damage in various organs (eg, liver) that can culminate in non-alcoholic fatty liver disease, non-alcoholic steatohepatitis, liver cirrhosis and hepatocellular carcinoma. ${ }^{37}$ At the pancreatic level, FA-associated toxicity may lead to dysfunction of $\beta$ cells. At the cardiac level, it may lead to the loss of myocardial contractility with consequent heart failure, whereas it may act as a precursor of neuroinflammatory processes in the brain. ${ }^{38}$

Lipotoxicity is a phenomenon characterised by increased levels of FAs. Also, increased amounts of FAs can induce the activation of various metabolic pathways that cause the uncoupling of cellular metabolism, with the generation of signalling cascades related to the start of programmed cell death and finally cellular energetic failure. ${ }^{39}$ In obesity, excessive consumption of foods rich in carbohydrates and excessive release of FAs by adipose tissue both exceed 


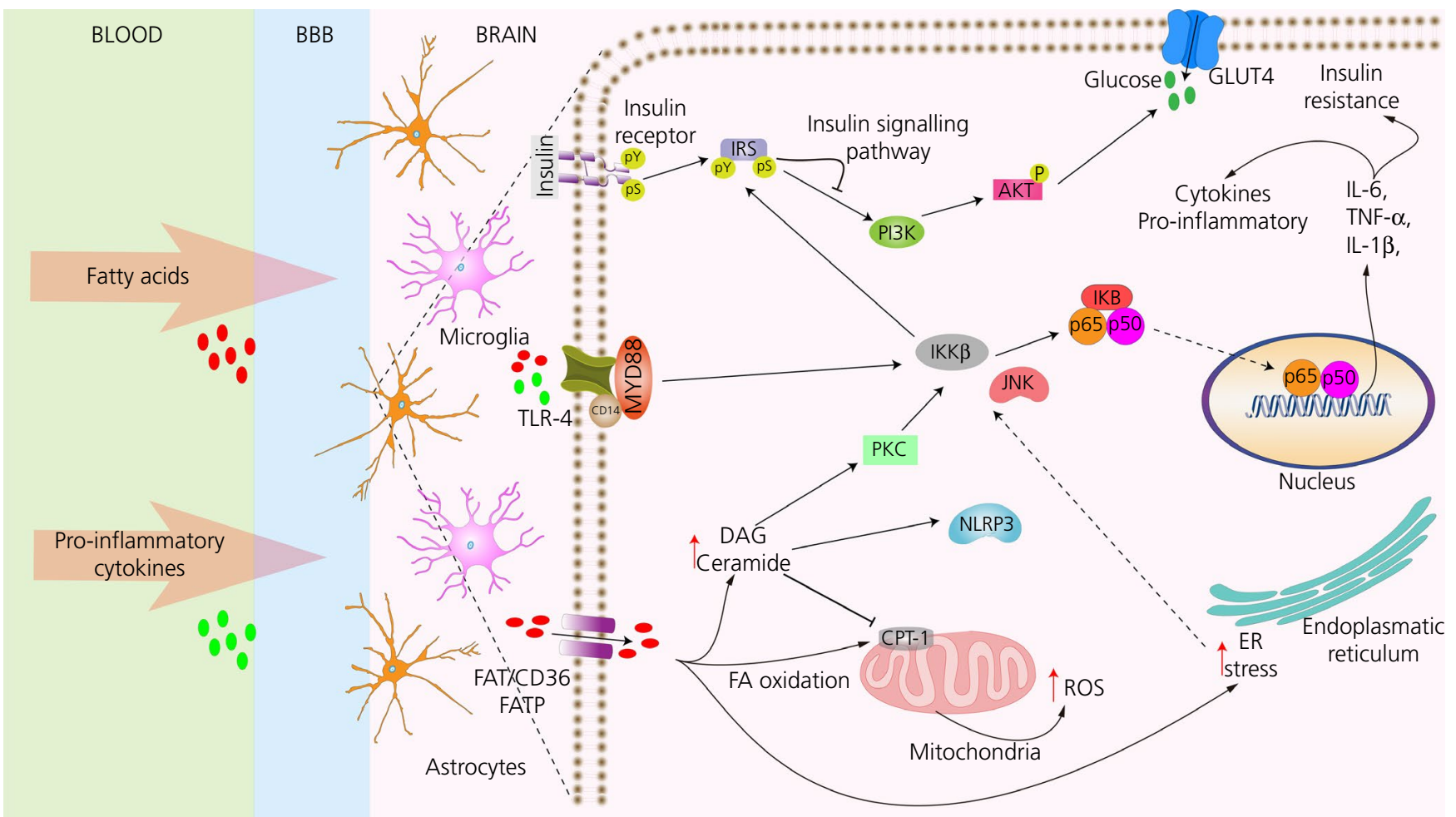

FIGURE 1 Fatty acids (FAs) induce inflammation in the nervous system and attenuate the signalling pathway of insulin in obesity. The excess of FAs produce inflammation principally by means of three mechanisms. Increase in lipotoxicity when the FA concentration exceeds the oxidative requirements, increasing the levels of diacylglycerol (DAG) and ceramide. DAG activates protein kinase $C$ (PKC), which activates the nuclear factor inhibitor NF-kB (IkB) kinase (IKK $\beta-N F-k B)$ pathway, causing inflammation. A high concentration of ceramides activates the nodule-type receptor that contains a purine domain (NLRP3), modulating the release of interleukin (IL)-1 $\beta$ and also leads to the activation of the protein phosphatase $2 \mathrm{~A}$ (PP2A), attenuating the signalling pathway of insulin. Palmitic acid dysregulates the function of the endoplasmic reticulum (ER) producing stress and inflammation via NF-kB, N-terminal c-Jun (JNK) and NLRP3 inflammasome, leading to further generation of reactive oxygen species (ROS) in mitochondria. Palmitic acid activates the toll-like receptor (TLR)-4 through fetuin A; likewise, high-fat diets increase lipopolysaccharide levels, an activator of this receptor, which leads to an increase in the activity of the IKK $\beta$ NF-kB pathway. BBB, blood brain-barrier; PI3K, phosphoinositide 3-kinase; TNF, tumour necrosis factor

the storage limit and the capacity of oxidation in different tissues. ${ }^{40}$ In this regard, FAs are redirected to harmful non-oxidative metabolic pathways, which are linked with the intracellular accumulation of toxic metabolites such as reactive oxygen species (ROS). ${ }^{41}$

The oxidation of FAs increases the proportion of acetyl coenzyme $\mathrm{A}$ /coenzyme $\mathrm{A}$ and $\mathrm{NADH} / \mathrm{NAD}^{+}$in mitochondria, which results in the inactivation of pyruvate dehydrogenase. ${ }^{42}$ Inactivation of this enzyme leads to the accumulation of citrate and subsequent inactivation of the enzyme phosphofructokinase. In turn, this latter inactivation leads to the accumulation of glucose 6-phosphate, which then stimulates the synthesis of glycogen and the inhibition of hexokinase, resulting in the inhibition of glucose uptake. ${ }^{43}$

Large amounts of FAs available at the cellular level that are not used by cellular activity can negatively alter the process of $\beta$-oxidation and affect cell/energy balance. When this process is impaired, the FAs are metabolised by alternative routes and are degraded or incorporated into other molecules. ${ }^{44}$ FAs can have damaging cellular effects by increasing the activity of the serine palmitoyl transferase that catalyses the condensation of palmitoyl coenzyme $A$ and serine to form dihydrosphingosine. This is the first step for the de novo synthesis of ceramide, a molecule involved in the regulation of cellular processes such as cellular differentiation and proliferation, in addition to cellular apoptosis, via the expression of the anti-apoptotic molecule Bcl2. ${ }^{45}$ The accumulation of metabolites involved in the synthesis of ceramides, along with other catabolic products of Fas, triggers a signalling network between the endoplasmic reticulum, the cell nucleus and the mitochondria. For example, FA alters important apoptotic factors of the endoplasmic reticulum such as inositol 1 recruiting protein (IRE1), transcription activating factor 6 and protein kinases such as the protein kinase $R$ of the endoplasmic reticulum (PERK). ${ }^{46}$ The intracellular accumulation of palmitic acid and stearic acid causes the activation of apoptosis via IRE1 and PERK in humans with non-alcoholic steatohepatitis. ${ }^{47}$ The mitochondria are the main cellular compartment affected by FAs, where an increase in mitochondrial $\beta$-oxidation, induction of cytochrome P450 and leukocyte infiltration result in the generation of oxidative stress and nitrogen-free radicals. ${ }^{48}$ Several studies on obesity and non-alcoholic steatohepatitis in male patients have revealed an increase in the expression of metabolites derived from oxidative stress caused by the excess of FAs. ${ }^{49}$ Some of these metabolites include 4-nitrotyrosine, 
hydroxynonenal, substances reactive to thiobarbituric acid (lipoperoxidation markers) and 8-hydroxydeoxyguanosine (a marker of DNA damage), amongst other biomarkers of oxidative stress. ${ }^{50}$

Several studies have shown that toll-like receptors (TLRs), which are responsible for transducing FA-induced signalling, recognise the pathogens and respond by activating the innate immune response. ${ }^{51,52}$ In macrophage cultures of female C57BL/6 mice, lauric acid could activate TLR4 receptor and dimerise with TLR2. ${ }^{53}$ TLR4 can also be activated by palmitic acid, thereby triggering the translocation to the nucleus of NF- $\mathrm{KB}$ and subsequent overexpression of the pro-inflammatory cytokines tumour necrosis factor (TNF) $\alpha$ and interleukin (IL)-6. ${ }^{54}$ These cytokines, in turn, contribute to the inflammatory process associated with obesity ${ }^{55}$ (Figure 1).

Previous studies have reported an association between highfat diets and cognitive decline in humans. ${ }^{56}$ In addition, a higher probability of suffering from dementia has been associated with the development of inflammatory processes and obesity. ${ }^{22} \mathrm{~A}$ sedentary lifestyle, a lack of physical activity and unhealthy eating habits have been catalogued as determining factors in the development of neurodegenerative diseases as a resukt of the inflammatory response that is generated in the brain. ${ }^{57}$ Furthermore, these factors may influence the outcome of other types of injuries that alter brain function, such as traumatic brain injury (TBI), thereby producing alterations in the cerebral energy machinery that prevent tissue repair and delay the recovery of cerebral function. ${ }^{58}$ Indeed, obesity, characterised by insulin resistance and the presence of neuroinflammatory processes, increases the consequences of TBI. ${ }^{59}$ This occurs because of the transient alteration of glucose demands and the presence of high concentrations of free FAs characteristic of obese patients. ${ }^{60}$

Some studies have reported an increase in the levels of saturated FAs in post-mortem human brains with TBI. ${ }^{61,62}$ In studies of male and female mice that underwent TBI, obesity was found to increase the activation of glial cells (astrocytes and microglia), the expression of neuroinflammatory factors, and the impairment of learning and memory processes. ${ }^{63}$ All of these alterations suggest that obese people have a reduced ability of the injured brain to respond with neuroprotective and anti-inflammatory actions. Therefore, obesity can be a contributing factor triggering neuroinflammation. ${ }^{64}$ Also, it has been well established that oestrogens play an essential role in the prevention of body weight gain. ${ }^{65}$ There is a strong relationship between the development of obesity, diabetes and the metabolic syndrome, with a dramatic drop in the circulating levels of $17 \beta$-oestradiol $\left(E_{2}\right)$ in post-menopausal women. ${ }^{66}$ Treatment with $E_{2}$ significantly reduces the risk of developing these pathologies ${ }^{67}$ because the action of $E_{2}$ on ERs triggers the activation of intracellular signals that counteract the inflammatory process. ${ }^{68}$ However, these therapeutic benefits provided by $\mathrm{E}_{2}$ can be accompanied by negative side effects, such as reproductive endocrine toxicity ${ }^{69}$ and the development of breast cancer. ${ }^{70}$ As a result of the above-mentioned side effects, the administration of oestrogen in post-menopausal women is not free from controversy and alternative compounds, such as tibolone, are being used in clinical practice (see further below).

\section{3 | LIPOTOXICITY, GLIAL CELLS, NEURODEGENERATION AND NEUROINFLAMMATION}

The release and presence of a large amount of saturated FAs in the bloodstream can affect brain function. The development of inflammatory processes in the nervous system represents a decisive risk factor for neurodegenerative diseases. These changes in the cerebral environment contribute to the activation of microglia as a mechanism of defence and repair; however, the presence of exacerbated and prolonged processes can trigger a deregulation in microglial activation, which will stimulate additional release of inflammatory factors by these cells. This can culminate in the elevated levels of several pro-inflammatory cytokines and the induction of a chronic neuroinflammatory environment, a situation that is associated with many neurodegenerative disorders, such as agerelated macular degeneration, $\mathrm{AD}$, multiple sclerosis, Parkinson's disease (PD), Huntington's disease and tauopathies. ${ }^{71}$

The increase in life expectancy in some countries is directly related to the increase in the prevalence of $A D .^{72} A D$ is mainly associated with ageing, with this being the main risk factor in the onset of this neurodegenerative pathology, ${ }^{73}$ although a higher risk has also been found in patients with obesity. Together with alterations in oxidative stress and mitochondrial dysfunction, ${ }^{74}$ the progression of $A D$ is directly linked to alterations in local immune responses, characterised by inflammation and activation of astrocytes and microglia. ${ }^{75}$ Indeed, neuroinflammation is involved in multiple pathological mechanisms of $A D$, and pro-inflammatory mediators such as IL-1 $\beta$, IL- 6 and TNF $\alpha$ have been shown to be associated with the disease. ${ }^{76}$

Chronic inflammation in AD is a general observation, ${ }^{77}$ whereas oxidative stress precedes neuronal damage. ${ }^{78}$ Other inflammatory mediators such as IL-1 $\beta$, transforming growth factor- $\beta$ and inducible cyclo-oxygenase- 2 have been found to be up-regulated in AD. ${ }^{76}$ Most studies and experimental evidence indicate that a pro-inflammatory environment promotes the development of $A D$, whereas anti-inflammatory treatment decreases its progression. ${ }^{79,80}$

Neuroinflammation may be neuroprotective at early stages but has chronic negative effects if the stimulus responsible for inflammation persists, causing over-activation of microglia and the increased release of cytokines. ${ }^{81}$ For example, amyloid plaques are surrounded by glia that secrete pro-inflammatory molecules, including TNF $\alpha, I L-1 \beta$ and monocyte chemoattractant protein (MCP)-1, which in turn increase neuronal sensitivity to free radicals and accelerate neurodegeneration. ${ }^{82}$ Another factor that favours neuroinflammation is inducible nitric oxide synthase, which has been found to be increased in the AD brains. ${ }^{83}$ The effects of treatment with non-steroidal anti-inflammatory drugs ${ }^{84}$ and oestrogens on the inflammatory processes involved in different diseases have been widely reported. ${ }^{85}$ As a result of the low oestrogen levels that have been found in obese patients with increased levels of free FAs, hormonal supplements have been 


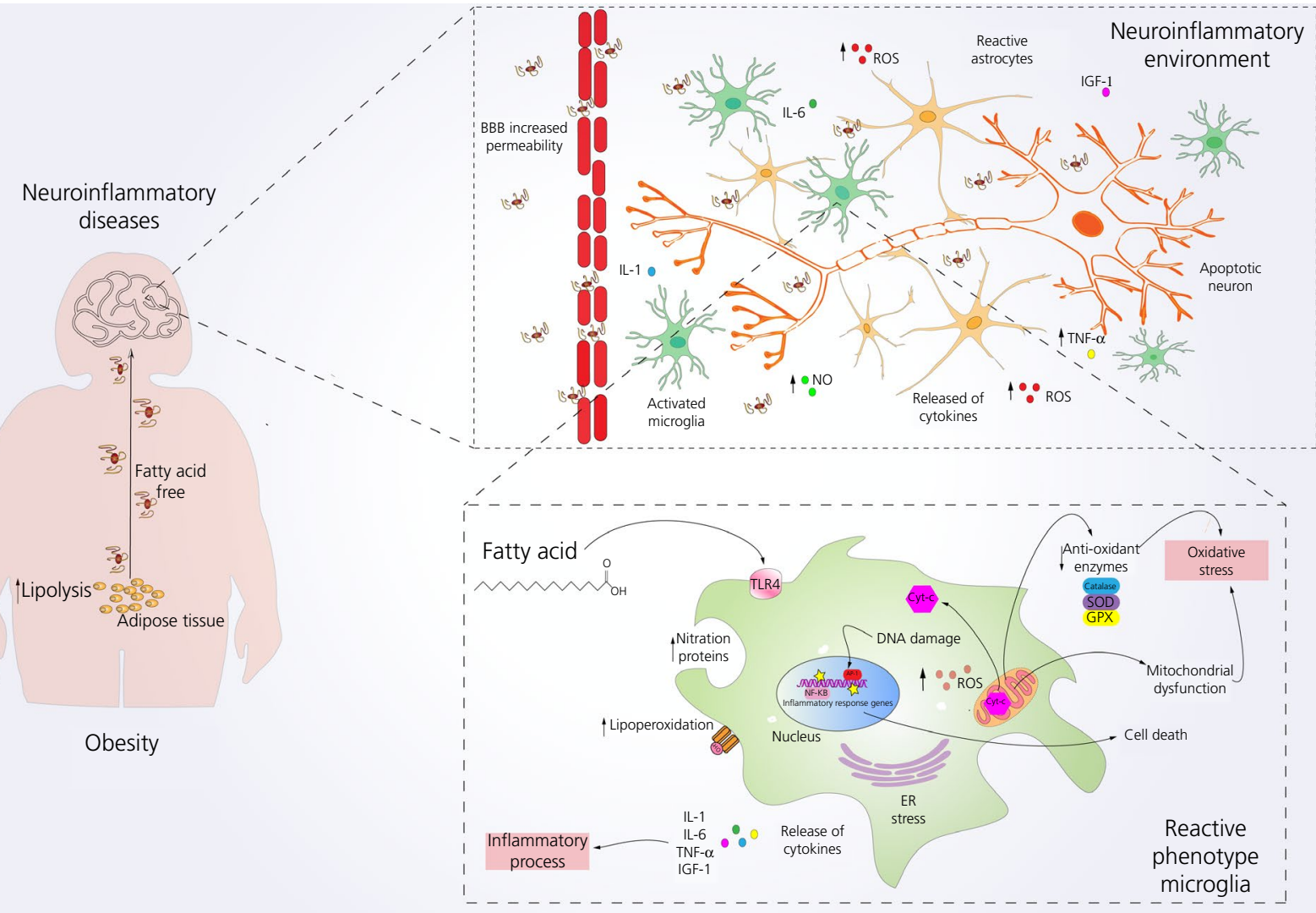

FIGURE 2 Effect of fatty acids (FA) on the central nervous system. Metabolic diseases such as obesity are characterised by the accumulation of multiple metabolites that generate alterations on physiological conditions. The excess of fatty acids can contribute to an increase in inflammatory processes directly affecting the brain. The increase in the blood brain-barrier (BBB) permeability facilitates the entry of FA and subsequent recognition by brain cells (neurones, astrocytes, microglia), triggering different response mechanisms that contribute to the appearance of a neuroinflammatory environment, as characterised by secretion of inflammatory cytokines, the activation of glial cells and neuronal death, amongst others. The activation of microglia implies morphological and functional changes from a chronic inflammation, by which signalling pathways and transcription factors related to apoptotic processes and cell death contribute to the risk of developing neurodegenerative diseases. ER, endoplasmic reticulum; IGF, insulin-like growth factor; IL, interleukin, ROS, reactive oxygen species; TNF, tumour necrosis factor

used $^{33,40}$ and this replacement therapy significantly decreased the risk of developing the disease ${ }^{47}$ (Figure 2).

$\mathrm{PD}$ is another neurodegenerative disease affected by the neuroinflammatory processes activated by FAs, representing the second most common neurodegenerative disorder after AD. It affects $1 \%-2 \%$ of the general population aged ober 65 years of age. ${ }^{86}$ One of the markers of neurodegeneration in PD is the abnormal accumulation of $\alpha$-synuclein protein in neurones, which triggers the activation of glial cells and the progression of inflammation. ${ }^{87}$ Reactive microglia have been observed in the substantia nigra of patients with $\mathrm{PD}$, which suggests that this inflammatory process could aggravate neurodegeneration. ${ }^{88}$ Indeed, active microglia and, to a lesser extent, reactive astrocytes are associated with neuronal loss. This is a result of the release of TNF $\alpha, I L-1 \beta$ and IL-6, prostaglandins (PGE2, PGD2), ROS and nitric oxide (NO). ${ }^{89}$ However, analysis of neuronal loss in patients with PD demonstrates that it is a heterogeneous process because neurones containing neuromelanin are predominantly involved. ${ }^{90}$ This leads to an increase in the pro-inflammatory molecules TNF $\alpha$, IL- 6 and NO that trigger neuroinflammatory processes.
It is noteworthy that neuromelanin has a crucial role in microglial activation, which leads to a vicious circle of neuronal death. ${ }^{91}$

\section{4 | OESTROGENS AND THE BRAIN}

Oestrogens play a vital role in both male and female reproductive physiology, stimulating cell growth and differentiation in various tissues such as breast, uterus, vagina, ovary, testis, epididymis and prostate. $^{92}$ It has been shown that oestrogens are of great importance in cardiovascular physiology; for example, the risk of cardiovascular disease is lower in women than in men before menopause. ${ }^{93}$ After menopause, the level of $E_{2}$, the oestrogen that predominates in the circulation before menopause, decreases to the level found in men of similar age and can sometimes be even lower. ${ }^{94}$ Oestrogens are required for neuronal growth and differentiation and are known to affect cognitive and mood functions. In addition, oestrogens can be useful in preventing or delaying the onset of degenerative diseases of the nervous system. Most actions of oestrogens in the 
brain are considered to be mediated by activation of $\operatorname{ER} \alpha, \operatorname{ER} \beta$ or $G$ protein-coupled receptor for oestrogen (GPER), and this topic is discussed below.

\section{1 | Role of oestrogenic compounds in glial cell function and inflammation}

ERs are proteins belonging to the superfamily of nuclear receptors, which also include other receptors for steroid hormones, the vitamin $D$ receptor, retinoids, thyroid hormone and some orphan receptors. ERs were identified approximately 40 years ago when, in 1962, the presence of oestrogen-binding sites in different tissues of rats was described. Two isoforms are currently known: ER $\alpha$ and ER $\beta{ }^{95}$ The ERs present a diverse subcellular localisation and can be detected in the cytoplasm, ${ }^{96}$ nucleus, ${ }^{97}$ mitochondria and endoplasmic reticulum. ${ }^{98}$ Both receptors (ER $\alpha$ and ER $\beta$ ) have different functions according to the tissue where they exert their actions. The classical theory of action of steroid hormones states that the steroid receptor is activated by binding to the ligand (in this case $E_{2}$ ) and acts as a transcription factor by binding to DNA and stimulating gene transcription. Because these nuclear receptors exert their actions in the nucleus, their mode of action is so termed genomic. ${ }^{99}$ The transcription stimulated by the ER is regulated in a tissue-specific manner. However, in addition to its canonical response, oestradiol can induce effects quickly and independently of genomic mechanisms. ${ }^{100}$ The non-genomic mode of action of oestradiol (and in general for all steroid hormones) is a rapid process that does not require the synthesis of new proteins, and is mediated by receptors localised in the membrane. ${ }^{101}$ The rapid oestrogenic action includes the regulation of ion fluxes, discharge of secretory vesicles and activation of protein kinases associated with the membrane. ${ }^{102}$ In 1967, the idea that oestradiol could induce its cellular effects via non-genomic mechanisms was introduced, as indicated by the increase in the production of cyclic AMP (cAMP) in vivo. ${ }^{103,104}$ Subsequently, it was demonstrated that $E_{2}$ increases the intracellular concentration of $\mathrm{Ca}^{2+}$ induced by glucose and cyclic GMP in beta cells of the pancreas. ${ }^{105}$

In the last decade, evidence has emerged concerning the role of GPER in the metabolic regulation of the nervous system. ${ }^{106}$ The GPER is a receptor coupled to the G protein of seven transmembrane domains, whereas its expression and distribution have been demonstrated in a wide variety of cells and tissues. ${ }^{107}$ The GPER is located in the plasma membrane, although many investigations have identified it in other subcellular compartments, particularly in the endoplasmic reticulum and the Golgi apparatus, ${ }^{108}$ suggesting possible role of oestrogen in these organelles.

It has been shown that oestradiol binds to the GPER and activates multiple signalling pathways. ${ }^{107}$ It is known that GPER exerts its effects via rapid non-genomic signalling and transcriptional activation. ${ }^{109,110}$ The mechanisms of action of this receptor depend on the type of tissue, as well as the abundance and expression of receptors. The rapid non-genomic signalling in response to $E_{2}$ via GPER can activate multiple signalling pathways, including mitogenactivated protein kinase, phosphoinositide 3-kinase, protein kinase
$\mathrm{C}, \mathrm{Ca}^{2+}$ and adenylyl cyclase, ${ }^{111-113}$ demonstrating the activation of some survival and metabolic downstream pathways. Depending on the cellular context, the GPER can mediate proliferative and survival responses. ${ }^{114}$ Although the mechanisms of action of the GPER are still unclear, it has also been described as a target of other molecules with oestrogenic activity, such as tamoxifen, which has been related to the regulation of functions in the central nervous system. ${ }^{115}$

There is a key regulatory role of the oestrogenic response in inflammatory processes. ${ }^{116,117}$ In inflammatory in vitro and in vivo models, it has been shown that administration of oestradiol and selective ER modulators (SERMs) decreases the expression of the pro-inflammatory cytokines IL-1 $\beta$, IL-10 and TNF $\alpha .{ }^{118,119}$ Raloxifene, another SERM, has also been shown to protect mitochondria in astrocytic cells exposed to glucose deprivation. ${ }^{120}$ By contrast, administration of oestradiol can modulate the mitogenic stimulation of $B$ and $\mathrm{T}$ lymphocytes and, as a consequence, increase the production of immunoglobulins such as immunoglobulin M. Indeed, epidemiological studies have shown that women of any age experience lower rates of infection and mortality associated with inflammatory processes compared to men. ${ }^{121}$

The relationship between the oestrogenic response and inflammation is also associated with the differential activity of the ER subtypes. ${ }^{122}$ For example, in patients with rheumatoid arthritis, a density analysis of ER $\alpha$ and $E R \beta$ in synoviocytes showed a greater presence of ER $\beta .^{121}$ The same trend is observed in patients with systemic lupus erythematosus, where T lymphocytes have a higher concentration of $E R \beta^{+}$lymphocytes than $E R \alpha^{+}$Iymphocytes. ${ }^{122}$ In the case of the nervous system, inflammation can be triggered by conditions such as oxidative stress, endotoxins, mechanical damage and chronic neurodegenerative diseases. ${ }^{123}$ Inflammation can be acute or chronic and the oestrogenic response can influence or modulate the two types of response, which can involve cellular components such as microglia and astrocytes. ${ }^{124-126}$ It has been shown that human astrocytes can secrete molecules associated with inflammation such as interleukins, as well as chemotactic factors such as MCP-1, macrophage inflammatory protein- $1 \alpha$ and interferon- $\gamma$-inducible protein $10 .{ }^{127}$ It was reported that astrocytes are actively involved in the secretion of pro-inflammatory molecules IL- 6 and interferon (INF) $\gamma .{ }^{116,128,129}$ Additionally, oestradiol has the ability to decrease the secretion of these inflammatory molecules in an oxidative model mediated by $\mathrm{H}_{2} \mathrm{O}_{2}$ following stimulation with lipopolysaccharide (LPS), for which the response is associated with the NF-kB pathway. ${ }^{130}$ This response is similar in astrocytes as a result of a reduction in the release of pro-inflammatory molecules in metabolic dysfunction models, ${ }^{131}$ such as stimulation with palmitic acid ${ }^{27}$ (Figure 3).

Some neurosteroids such as dehydroepiandrosterone modulate microglial activation and the immune response in vitro. ${ }^{132}$ In in vivo experiments, neuroactive steroids inhibited TNF $\alpha$ and INF $\gamma$ in astrocytes and microglia. ${ }^{133}$ By contrast, progesterone did not inhibit the immune responses of microglia ${ }^{85}$ but prevented morphological changes associated with activated microglia phenotype. ${ }^{134}$ Additionally, other studies reported that progesterone did not have 


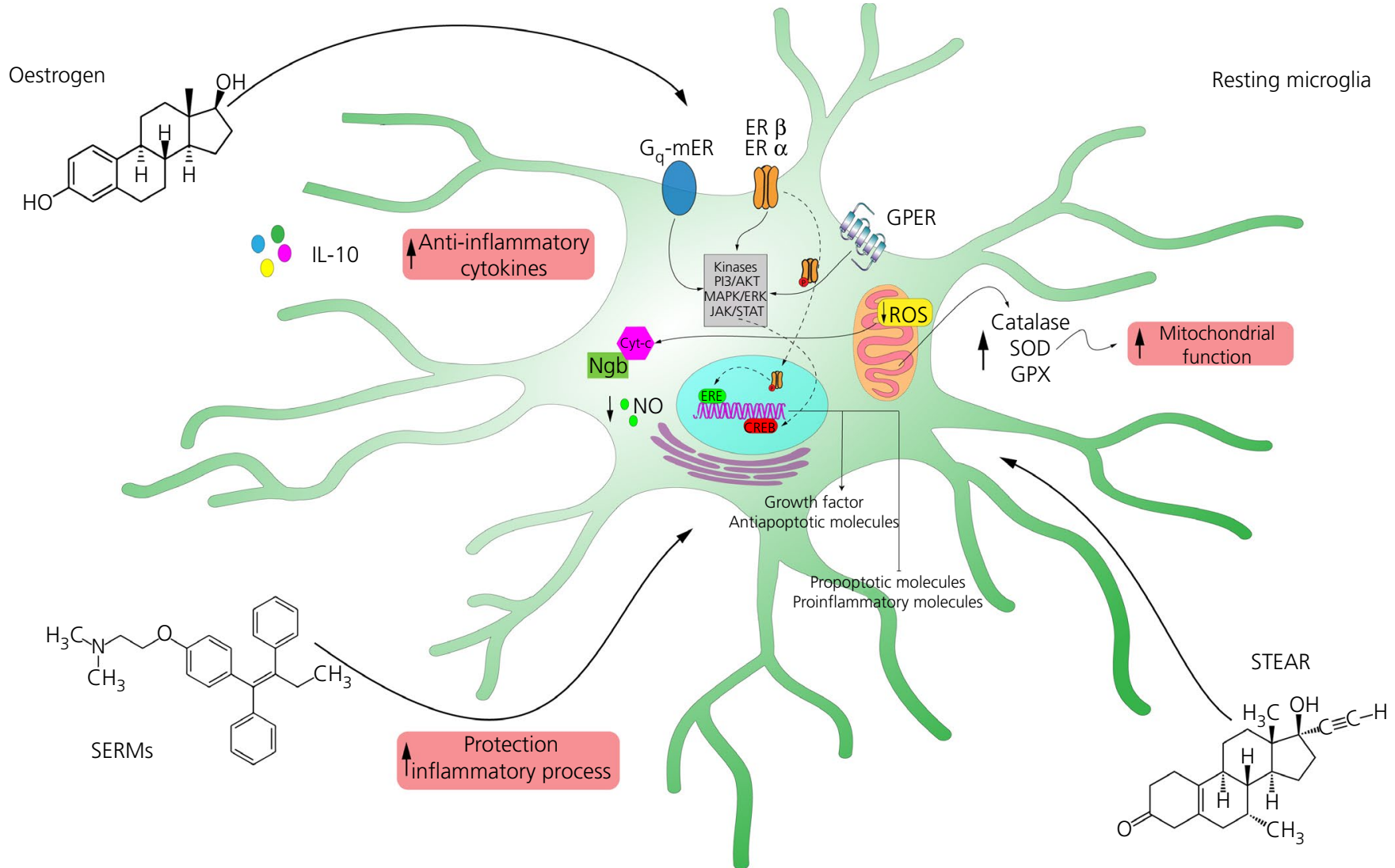

FIGURE 3 Neurosteroids and neuroactive steroids have protective effects on the central nervous system cells. Treatment with oestradiol, selective oestrogen receptor modulators (SERMs) and selective tissue-specific oestrogenic activity regulators (STEARs) has protective effects on the integrity of the cerebral microenvironment. Different investigations have reported that these molecules recover mitochondrial functions, oxidative stress, reduce the release of inflammatory factors (chemokines, cytokines, etc.) and attenuate the expression of proinflammatory and pro-apoptotic proteins and genes. This protection is a result of the activation of oestrogen receptors and G protein-coupled receptor for oestrogen (GPER), amongst others, where, via genomic and non-genomic mechanisms, they activate the antiinflammatory response and cell survival. ER, endoplasmic reticulum; IL, interleukin, ROS, reactive oxygen species

anti-inflammatory effects on mixed cultures of astrocytes and microglia but inhibited microglial proliferation in separate cultures. ${ }^{135}$

Both central and peripheral steroids participate in the activation and protection of the brain, in particular during the aging process and after an injury. ${ }^{136}$ The neuroprotective actions of steroids have been reported in several studies, in which it was shown that these compounds have a highly specific affinity to their nuclear receptors and mediate several protective functions, among which are the increase in the levels of anti-inflammatory factors and anti-apoptotic factors, as well as a decrease in the expression of inflammatory mediators. ${ }^{137}$ Pregnenolone and dehydroepiandrosterone are known to promote the survival and differentiation of neuronal cells grown from embryonic rat brain. ${ }^{138}$ In a similar way, oestradiol, tamoxifen and raloxifene reduced the activation of microglia in male and female rats after peripheral inflammation induced by the administration of LPS. This latter effect was proposed to be mediated by a mechanism that may involve ER in microglia, thereby improving cell survival depending on the sex. ${ }^{139}$

The classical mechanism of action of steroid hormones in the brain is via interaction with their intracellular receptors (ERs, progesterone and androgen receptors). ${ }^{140,141}$ The expression of these receptors by glial cells allows them to partially mediate the action of oestrogenic compounds in the brain. ${ }^{118}$ Indeed, the response induced by each receptor stimulates cell survival, differentiation and connectivity of neurones and glial cells in the brain, including the medulla. ${ }^{102}$ Also, neurosteroids play an important role in the development of the prenatal CNS, at the same time as regulating behaviour and neuroendocrine signalling in the adult brain. ${ }^{142}$ Although many of the signalling pathways activated by oestrogen are known, the anti-inflammatory molecular mechanisms are not completely clear. ${ }^{143}$

Many of the neurodegenerative diseases are characterised by the development of brain inflammation as a consequence of injuries or metabolic damage. ${ }^{59}$ As noted above, inflammation in the nervous system can be triggered by conditions such as oxidative stress, endotoxins, cytokine secretion, mechanical injury and chronic neurodegenerative pathologies. ${ }^{12}$ This inflammation can be acute or chronic, and the cellular components of the nervous system such as microglia or astroglia, can respond to oestrogenic activity by modulating these inflammatory processes. ${ }^{126}$ 
Body weight increases in several conditions associated with hormonal decline. In women, oestrogens favour the deposition of fat in some parts of the body; however, after menopause, the fat subcellular localisation changes, being more similar to men. ${ }^{144}$ The adipose tissue is capable of producing oestrogens via the aromatisation of androgens and an increase in the blood concentration of oestrogens has been observed in men with obesity, although this is not evident in women. ${ }^{145}$ It has been demonstrated that ER $\alpha$ is the main isoform that participates in the control of weight by oestrogens and the absence of ER $\alpha$ produces hyperplasia and hypertrophy of the adipocytes. ${ }^{146}$

Taking into account alterations in plasma oestrogen levels, an increase in free saturated FAs and the infiltration of pro-inflammatory agents together present the ideal scenario for the development of neurodegenerative diseases. Oestrogens play a fundamental role in the prevention of obesity. ${ }^{147}$ Studies in female mice showed a weight gain and hyperadiposity after ovariectomy, which eliminates endogenous oestrogens. Interestingly, treatment with oestradiol reduced the development of this obese phenotype, ${ }^{148}$ demonstrating that these effects on the homeostasis of body weight are mediated mainly by the activation of ER. ${ }^{149}$ Humans or mice with mutations in the ER gene (ESR1) are obese. ${ }^{150}$ Similalrly, oestradiol therapy was found to have no effect in mice subjected to ER suppression. ${ }^{151}$

The oestrogenic response associated with inflammatory processes has been found to have the ability to decrease the secretion of inflammatory molecules and reduce the production of ROS. ${ }^{152}$ In this regard, it was reported that this mechanism was associated with the response of ER via the activation of the inflammatory pathway NF- $\mathrm{kB},{ }^{153,154}$ as well as the expression and modification of some proteins such as neuroglobin. ${ }^{24}$ For example, neuroglobin is a monomeric globin protein of approximately 150 amino acids ${ }^{155}$ that has the capacity to transport and store oxygen as a result of the haem group that it contains. ${ }^{156}$ Hormonal regulation of neuroglobin and protective mechanisms are discussed in more details below.

\subsection{Signalling mechanisms associated with oestrogen-induced neuroprotection}

Neuroglobin has been studied in different models of damage such as focal cerebral ischaemia, $\beta$-amyloid peptide-mediated toxicity, anoxia, and glucose and oxygen deprivation. ${ }^{157}$ The presence of neuroglobin, once assumed to be expressed only in neurones, has recently been discovered in glial cells. Although the neuroprotective effects of neuroglobin have been identified in these models, its molecular mechanisms of action are not yet well established. ${ }^{158,159}$ Several investigations have found that oestrogens and androgens can regulate the expression of neuroglobin; hence, the modulation of this protein by oestrogenic activity ${ }^{160}$ could be partly responsible for the protective effects of oestradiol in models of oxidative stress. ${ }^{157}$

Despite its broad spectrum of protective effects, the molecular mechanisms of action of neuroglobin are poorly understood. ${ }^{161}$ It has recently been shown that neuroglobin is a hormone-inducible protein. ${ }^{162}$ Neuroglobin has the potential to be a hypoxia signalling molecule, free radical scavenger or NADH oxidase capable of supporting anaerobic glycolysis. ${ }^{161}$ Several lines of evidence regarding tendency of neuroglobin to auto-oxidate, as well as its low concentration in the brain (approximately $1 \mu \mathrm{mol} \mathrm{L}^{-1}$ ) and its low affinity for oxygen, suggest that neuroglobin could play different roles ranging from oxygen storage to facilitating its diffusion. ${ }^{163,164}$ Additionally, photoactivation experiments of $\mathrm{NADH} /$ flavin mononucleotide that induce a reducing state in neuroglobin suggest that this protein participates in the elimination of oxygen radicals, mainly by reacting with $\mathrm{NO}$ to form a peroxynitrite radical that converts to the more stable form nitrite. ${ }^{165}$ The previous mechanism suggests a protective role for neuroglobin in the regulation of highly reactive species such as peroxynitrite. ${ }^{166}$ Under conditions of normoxia, neuroglobin is bound to oxygen, whereas, under hypoxic conditions, and according to deoxygenation experiments, neuroglobin adopts a hexacoordinated structure. ${ }^{163,167}$ This structure can be a signal indicating the low levels of oxygen in the cellular environment, triggering events to protect the cell from death. ${ }^{116}$ Therefore, overexpression of neuroglobin could increase survival in conditions of low oxygen levels. Additionally, hypoxia produces a $\mathrm{pH}$ decrease and this condition also favours the hexacoordinated conformation of neuroglobin. ${ }^{167,168}$ Interestingly, neuroglobin is a hormone-regulated protein, ${ }^{24,32,130,160}$ suggesting that oestrogenic compounds (oestradiol and tibolone) or androgens (testosterone) can modulate its expression. The protective actions of tibolone are discussed below.

\section{5 | TIBOLONE: A NEUROACTIVE STEROID AND REGULATOR OF OESTROGENIC ACTIVITY}

The family of drugs acting as selective tissue-specific oestrogenic activity regulators is termed STEAR. ${ }^{169}$ The most representative molecule of this family of drugs is tibolone. ${ }^{170}$ Tibolone is considered as a synthetic steroid with oestrogenic, progestogenic and androgenic activity. ${ }^{171}$ Tibolone is prescribed for the treatment of climacteric symptoms in post-menopausal women. ${ }^{172}$

Tibolone has a 3-keto- $\delta 5-10$ configuration, a $7 \alpha$-methyl substituent, and a $17 \alpha$-ethynyl group that per se cannot explain its combined effects in different tissues such as vagina, bones and brain. ${ }^{170}$ Additionally, this compound mimics the activity of oestradiol neither via an aromatic ring, nor via the $3-\mathrm{OH}$ substituent, which is necessary to act as an agonist of ER. ${ }^{77}$ Its similar activity to oestradiol is probably a result of the hydroxyl groups and isomeric metabolites.

Tibolone is rapidly metabolised in the body to three different metabolites: (i) $3 \alpha$ - and (ii) $3 \beta-\mathrm{OH}$-tibolone, metabolised by the enzymes $3 \alpha / \beta$ hydroxy-steroid dehydrogenase (HSD), respectively, and (iii) $\delta 4$-tibolone also called $\delta 4$-isomer, metabolised by the enzyme $3 \beta$-HSD-isomerase, ${ }^{77}$ which together explain the combined activity of tibolone. Specifically, clinical evidence has indicated that $3 \alpha$ - and $3 \beta-\mathrm{OH}$-tibolone metabolites are responsible for the oestrogenic activity, whereas 84 -tibolone is associated with the progestogenic and androgenic activity, as determined by its ability to interact with androgen and progesterone receptors. ${ }^{169}$ Similar to one of the 
TAB LE 1 Studies on the relationship between fatty acids and oestrogen in the brain

\begin{tabular}{|c|c|c|c|}
\hline Reference & In vitro/in vivo model & Aims & Results \\
\hline 16 & $\begin{array}{l}\text { Microglial cell line BV-2 and } \\
\text { primary microglia }\end{array}$ & $\begin{array}{l}\text { Effect of palmitic acid and stearic acid on mi- } \\
\text { croglial activation and their relationship with } \\
\text { Alzheimer's disease }\end{array}$ & 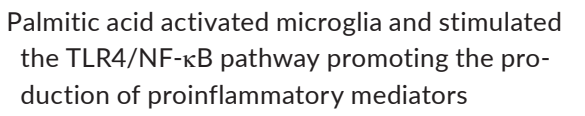 \\
\hline 27 & $\begin{array}{l}\text { Primary astrocytes derived } \\
\text { from male and female } \\
\text { Wistar rat hippocampus }\end{array}$ & $\begin{array}{l}\text { Effects of oestradiol in astrocytes exposed } \\
\text { to palmitic acid, with important sex-related } \\
\text { outcomes }\end{array}$ & $\begin{array}{l}\text { Palmitic acid increased the ER stress and } \\
\text { induced cell death. Oestradiol increased the } \\
\text { levels of protective factors in astrocytes of } \\
\text { both sexes, with a clear sex dimorphic response }\end{array}$ \\
\hline 31 & T98G human astrocytic & $\begin{array}{l}\text { Effect of tibolone on mitochondrial function in } \\
\text { human astrocytes exposed to palmitic acid }\end{array}$ & $\begin{array}{l}\text { Tibolone improved cell survival and preserved } \\
\text { mitochondrial membrane potential in astrocytic } \\
\text { cells treated with palmitic acid. }\end{array}$ \\
\hline 10 & $\begin{array}{l}\text { Mouse BV-2 microglia } \\
\text { cells, exposed to LPS and } \\
\text { palmitic acid }\end{array}$ & $\begin{array}{l}\text { Effects of free fatty acids on the microglial } \\
\text { response to inflammatory stimuli }\end{array}$ & $\begin{array}{l}\text { Palmitic acid induced the alternative activation } \\
\text { of microglia cells, affected the mRNA levels } \\
\text { of the proinflammatory cytokines la-1 } 1 \beta \text { and } \\
\text { interleukin- } 6\end{array}$ \\
\hline 181 & $\begin{array}{l}\text { Human neuroblastoma } \\
\text { cells SH-SY5Y and human } \\
\text { glioblastoma cells T98G }\end{array}$ & $\begin{array}{l}\text { Neuroinflammation and reactive gliosis are as- } \\
\text { sociated with the elevation of saturated fatty } \\
\text { acids related to the high-fat diet }\end{array}$ & $\begin{array}{l}\text { Palmitic acid induced apoptosis by increasing } \\
\text { oxidative stress in neurones and astrocytes }\end{array}$ \\
\hline 182 & $\begin{array}{l}\text { Ovariectomised C57BL/6 } \\
\text { female mice subjected } \\
\text { to brain injury with sub- } \\
\text { sequent treatment with } \\
\text { tibolone }\end{array}$ & $\begin{array}{l}\text { Evaluated the effect of tibolone on reactive } \\
\text { gliosis in the cerebral cortex after brain injury } \\
\text { in ovariectomised adult female mice }\end{array}$ & $\begin{array}{l}\text { Tibolone exerted beneficial homeostatic actions } \\
\text { in the cerebral cortex after acute brain injury }\end{array}$ \\
\hline 183 & $\begin{array}{l}\text { High-fat diets in hypotha- } \\
\text { lamic neurones and as- } \\
\text { trocytes of male C57BL/6 } \\
\text { mice }\end{array}$ & $\begin{array}{l}\text { Demonstrate that hypothalamic PGC-1 } \alpha \text { regu- } \\
\text { lates } E R \alpha \text { and inflammation in vivo }\end{array}$ & $\begin{array}{l}\text { PGC-1 } \alpha \text { depletion with ER } \alpha \text { overexpression } \\
\text { significantly inhibited palmitic acid-induced } \\
\text { inflammation, confirming that ER } \alpha \text { is a critical } \\
\text { determinant of the anti-inflammatory response }\end{array}$ \\
\hline
\end{tabular}

ER, oestrogen receptor; NF-kB, nuclear factor-kappa B; TLR, Toll-like receptor.

predominant forms of oestrogen (oestradiol), tibolone is metabolised to weak sulphated oestrogenic forms that serve as a substrate of sulphatase-type enzymes for the permanent production of oestrogenic metabolites in different tissues. ${ }^{173}$

Tibolone and its metabolites have different types of activities (progestogenic, androgenic and oestrogenic) in different tissue types (liver, bone, breast tissue and brain, amongst others), depending on the selective modulation of the receptors with which they interact. ${ }^{174}$ In studies where an oestrogenic compound $\left(E_{2}\right)$ was used in models of cerebral ischaemia in mice, it was demonstrated that the activation of the ER $\beta$ is neuroprotective against the damage. ${ }^{175}$ Similarly, another study investigated the neuroprotective effects of oestradiol and an ER $\alpha$ ligand using a model of multiple sclerosis. In the absence of anti-inflammatory effects, it was found that treatments based on the ER $\beta$ would potentially allow the development of neuroprotective strategies for different neurodegenerative diseases, whereas the use of ER $\alpha$ ligands should be restricted because of side effects in the womb and uterus. ${ }^{176}$ By contrast, other studies reported neuroprotection mediated by the ER $\alpha$ via signalling mechanisms mediated exclusively by astrocytes. ${ }^{177}$

In addition to oestrogenic compounds, progestogens and androgens have been studied in animal models for neurodegenerative diseases, indicating their neuroprotective potential. In the case of progestogens, it has been reported that their synthesis can be induced by oestradiol in astrocytes, ${ }^{178}$ suggesting not only the importance of oestradiol on progesterone synthesis, but also their combined action with other steroids. The progestogenic activity of tibolone is of great interest given that protective effects mediated by progesterone (pre- and post-insult) have been reported in different models that mimic the physiopathological conditions of important neurodegenerative diseases, such as oxidative insults by glutamate cytotoxicity and glucose deprivation, amongst others. ${ }^{179}$ In the CNS, different brain areas such as the hippocampus, cerebral cortex, spinal cord and sciatic nerve exhibit this protective effect of tibolone ${ }^{180}$ (Table 1 ).

Interestingly, the actions of tibolone in the brain are partly mediated by ER $\beta$. Tibolone has been shown to induce protective effects in both microglia and astroglial cells upon different inflammatory stimuli. ${ }^{23,24,29-32}$ For example, astrocytic cells exposed to glucose deprivation present more fragmented nuclei and increased levels of oxidative stress. Treatment of cells with tibolone (10 $\mathrm{nmol} \mathrm{L}{ }^{-1}$ ) or diarylpropionitrile (an ER $\beta$ agonist) but not with propylpyrazole-triol (an ER $\alpha$ agonist) preserved mitochondrial function and improved the outcome in a similar fashion, ${ }^{24}$ suggesting an oestrogenic action of tibolone in astrocytes. However, after blocking ER $\beta$ using an antagonist, protection with tibolone in astrocytic cells deprived of glucose is dampened and more cell death is observed. ${ }^{24}$ Similarly, in BV-2 microglial cells exposed to lipotoxicity with palmitic acid, cells treated with tibolone are rescued by a mechanism that involves ER $\beta$ and neuroglobin. In this 
regard, several studies have shown that neuroglobin expression is increased in both astrocytes and microglial cells after treatment with oestradiol, testosterone and tibolone, suggesting that this protein is hormonally regulated. Blocking the expression of neuroglobin using small interfering RNA reduced the protective effects of tibolone in microglia and astrocytes subjected to metabolic dysfunction. ${ }^{24,32}$ It has also been shown that tibolone induces protection in glial cells by epigenetic mechanisms, and these include the regulation of IL-6, microRNA, telomerase reverse transcriptase, DNA methylation and telomeric complex. ${ }^{29,30}$

\section{CONCLUSIONS}

The excess of free saturated FAs in the circulation has direct effects on the homeostasis and the functioning of the CNS. Free saturated FAs have consequences on different cells of the brain and their compartments. The main effects are demonstrated at the mitochondrial level, where an increase in oxidative stress contributes to the activation of inflammatory mechanisms that could lead to cell death. In the last decade, and as shown in this review, treatment with neuroactive steroids has been of great interest because of the fundamental protective role that they have on the CNS. Neuroactive steroids can be characterised by their anti-oxidant and anti-apoptotic properties, as well as their capacity to decrease glial activity. These protective effects on the survival and modulation of astrocytes and microglia are both dependent on and independent of the ERs, which trigger the activation of signalling pathways and the transcription factors of genes involved in the inflammatory response and cell protection. Therefore, neuroactive steroids such as tibolone and oestradiol are promising therapeutic candidates for the treatment of pathologies that affect the CNS with respect attenuating the progression of diseases related to exacerbated inflammatory processes. Future clinical studies on the use of steroids in the CNS diseases are warranted.

\section{AUTHOR CONTRIBUTIONS}

OHL, GEB, LMGS, RCM conceived and designed the study. OHL, GEB, LMGS, RCM, EBJ, VE, GMA and AS wrote the manuscript. All authors approved the final version of the manuscript submitted for publication.

\section{CONFLICT OF INTERESTS}

The authors declare that they have no conflicts of interest.

\section{ORCID}

Roberto C. Melcangi (iD https://orcid.org/0000-0003-0861-8967

George E. Barreto (iD https://orcid.org/0000-0002-6644-1971

\section{REFERENCES}

1. Karelis AD, Faraj M, Bastard JP, et al. The metabolically healthy but obese individual presents a favorable inflammation profile. J Clin Endocrinol Metab. 2005;90:4145-4150.

2. De Zwaan M, Mitchell JE, Howell LM, et al. Two measures of health-related quality of life in morbid obesity. Obes Res. 2002;10:1143-1151.

3. Mattson MP, Chan SL, Duan W. Modification of brain aging and neurodegenerative disorders by genes, diet, and behavior. Physiol Rev. 2002;82:637-672.

4. Jump DB. Fatty acid regulation of gene transcription. Crit Rev Clin Lab Sci. 2004;41:41-78.

5. Sampath H, Ntambi JM. Polyunsaturated fatty acid regulation of genes of lipid metabolism. Annu Rev Nutr. 2005;25:317-340.

6. Pekny M, Pekna M. Astrocyte reactivity and reactive astrogliosis: costs and benefits. Physiol Rev. 2014;94:1077-1098.

7. Pedraza-Alva G, Perez-Martinez L, Valdez-Hernandez L, MezaSosa KF, Ando-Kuri M. Negative regulation of the inflammasome: keeping inflammation under control. Immunol Rev. 2015;265:231-257.

8. Moser VA, Uchoa MF, Pike CJ. TLR4 inhibitor TAK-242 attenuates the adverse neural effects of diet-induced obesity. J Neuroinflammation. 2018;15:306.

9. Colton CA. Heterogeneity of microglial activation in the innate immune response in the brain. I Neuroimmune Pharmacol. 2009;4:399-418.

10. Tracy LM, Bergqvist F, Ivanova EV, Jacobsen KT, Iverfeldt K. Exposure to the saturated free fatty acid palmitate alters BV-2 microglia inflammatory response. J Mol Neurosci. 2013;51:805-812.

11. Martin-Jimenez CA, Garcia-Vega A, Cabezas R, et al. Astrocytes and endoplasmic reticulum stress: a bridge between obesity and neurodegenerative diseases. Prog Neurobiol. 2017;158:45-68.

12. Amor S, Peferoen LA, Vogel DY, et al. Inflammation in neurodegenerative diseases-an update. Immunology. 2014;142:151-166.

13. Karve IP, Taylor JM, Crack PJ. The contribution of astrocytes and microglia to traumatic brain injury. $\mathrm{Br} J$ Pharmacol. 2016;173:692-702.

14. Haversen L, Danielsson KN, Fogelstrand L, Wiklund O. Induction of proinflammatory cytokines by long-chain saturated fatty acids in human macrophages. Atherosclerosis. 2009;202:382-393.

15. Niu G, Li J, Wang H, Ren Y, Bai J. Associations of A-FABP with anthropometric and metabolic indices and inflammatory cytokines in obese patients with newly diagnosed type 2 diabetes. Biomed Res Int. 2016;2016:9382092.

16. Wang Z, Liu D, Wang F, et al. Saturated fatty acids activate microglia via Toll-like receptor 4/NF-kappaB signalling. Br J Nutr. 2012;107:229-241.

17. Arevalo MA, Santos-Galindo M, Acaz-Fonseca E, Azcoitia I, GarciaSegura LM. Gonadal hormones and the control of reactive gliosis. Horm Behav. 2013;63:216-221.

18. Sochocka M, Diniz BS, Leszek J. Inflammatory response in the CNS: friend or foe? Mol Neurobiol. 2017;54:8071-8089.

19. Nilsen J, Brinton RD. Mitochondria as therapeutic targets of estrogen action in the central nervous system. Curr Drug Targets CNS Neurol Disord. 2004;3:297-313.

20. Giatti S, Garcia-Segura LM, Barreto GE, Melcangi RC. Neuroactive steroids, neurosteroidogenesis and sex. Prog Neurobiol. 2019;176:1-17

21. Avila MF, Torrente D, Cabezas R, et al. Structural insights from GRP78-NF-kappaB binding interactions: a computational approach to understand a possible neuroprotective pathway in brain injuries. J Theor Biol. 2014;345:43-51.

22. Martin-Jimenez CA, Gaitan-Vaca DM, Echeverria V, Gonzalez J, Barreto GE. Relationship between obesity, Alzheimer's disease, 
and Parkinson's disease: an astrocentric view. Mol Neurobiol. 2017; 54:7096-7115.

23. Avila Rodriguez M, Garcia-Segura LM, Cabezas R, et al. Tibolone protects T98G cells from glucose deprivation. J Steroid Biochem Mol Biol. 2014;144:294-303.

24. Avila-Rodriguez M, Garcia-Segura LM, Hidalgo-Lanussa O, Baez E, Gonzalez J, Barreto GE. Tibolone protects astrocytic cells from glucose deprivation through a mechanism involving estrogen receptor beta and the upregulation of neuroglobin expression. Mol Cell Endocrinol. 2016;433:35-46.

25. Martin-Jimenez C, Gaitan-Vaca DM, Areiza N, et al. Astrocytes mediate protective actions of estrogenic compounds after traumatic brain injury. Neuroendocrinology. 2019;108:142-160.

26. Sribnick EA, Ray SK, Banik NL. Estrogen prevents glutamate-induced apoptosis in C6 glioma cells by a receptor-mediated mechanism. Neuroscience. 2006;137:197-209.

27. Frago LM, Canelles S, Freire-Regatillo A, et al. Estradiol uses different mechanisms in astrocytes from the hippocampus of male and female rats to protect against damage induced by palmitic acid. Front Mol Neurosci. 2017;10:330.

28. Ortiz-Rodriguez A, Acaz-Fonseca E, Boya P, Arevalo MA, GarciaSegura LM. Lipotoxic effects of palmitic acid on astrocytes are associated with autophagy impairment. Mol Neurobiol. 2019;56:1665-1680.

29. Gonzalez-Giraldo Y, Forero DA, Echeverria V, Garcia-Segura LM, Barreto GE. Tibolone attenuates inflammatory response by palmitic acid and preserves mitochondrial membrane potential in astrocytic cells through estrogen receptor beta. Mol Cell Endocrinol. 2019;486:65-78

30. Gonzalez-Giraldo Y, Garzon-Benitez AV, Forero DA, Barreto GE (in press). TERT inhibition leads to reduction of IL6 expression induced by palmitic acid and interferes with the protective effects of tibolone in an astrocytic cell model. J Neuroendocrinol. 2019;e12768.

31. Gonzalez-Giraldo Y, Garcia-Segura LM, Echeverria V, Barreto GE. Tibolone preserves mitochondrial functionality and cell morphology in astrocytic cells treated with palmitic acid. Mol Neurobiol. 2018;55:4453-4462.

32. Hidalgo-Lanussa O, Avila-Rodriguez M, Baez-Jurado $\mathrm{E}$, et al. Tibolone reduces oxidative damage and inflammation in microglia stimulated with palmitic acid through mechanisms involving estrogen receptor beta. Mol Neurobiol. 2018;55:5462-5477.

33. Large V, Peroni O, Letexier D, Ray H, Beylot M. Metabolism of lipids in human white adipocyte. Diabetes Metab. 2004;30:294-309.

34. Xu C, Xu GH. Adipose triglyceride lipase regulates adipocyte lipolysis. Sheng Li Ke Xue Jin Zhan. 2008;39:10-14.

35. Miyoshi H, Perfield JW 2nd, Souza SC, et al. Control of adipose triglyceride lipase action by serine 517 of perilipin A globally regulates protein kinase A-stimulated lipolysis in adipocytes. J Biol Chem. 2007;282:996-1002.

36. Li K, Wahlqvist ML, Li D. Nutrition, one-carbon metabolism and neural tube defects: a review. Nutrients. 2016;8:E741.

37. Varin $\mathrm{A}$, Thomas $\mathrm{C}$, Ishibashi $\mathrm{M}$, et al. Liver $\mathrm{X}$ receptor activation promotes polyunsaturated fatty acid synthesis in macrophages: relevance in the context of atherosclerosis. Arterioscler Thromb Vasc Biol. 2015;35:1357-1365.

38. Schonfeld P, Reiser G. Inhibition of beta-oxidation is not a valid therapeutic tool for reducing oxidative stress in conditions of neurodegeneration. J Cereb Blood Flow Metab. 2017;37:848-854.

39. Hauck AK, Bernlohr DA. Oxidative stress and lipotoxicity. J Lipid Res. 2016;57:1976-1986.

40. Zlobine I, Gopal K, Ussher JR. Lipotoxicity in obesity and diabetes-related cardiac dysfunction. Biochim Biophys Acta. 2016;1860:1555-1568.

41. Ruiz-Ramirez A, Lopez-Acosta O, Barrios-Maya MA, El-Hafidi M. Cell death and heart failure in obesity: role of uncoupling proteins. Oxid Med Cell Longev. 2016:2016:9340654.
42. Randle PJ, Garland PB, Hales CN, Newsholme EA. The glucose fatty-acid cycle. Its role in insulin sensitivity and the metabolic disturbances of diabetes mellitus. Lancet. 1963;1:785-789.

43. Gong ZG, Zhang J, Xu YJ. Metabolomics reveals that momordica charantia attenuates metabolic changes in experimental obesity. Phytother Res. 2017;31:296-302.

44. Gries FA, Oberdisse K. Lipid metabolism disorders and diabetes mellitus. Dtsch Med Wochenschr. 1970;95:727-734.

45. Unger RH. Lipotoxic diseases. Annu Rev Med. 2002;53:319-336.

46. Puri $P$, Mirshahi F, Cheung $O$, et al. Activation and dysregulation of the unfolded protein response in nonalcoholic fatty liver disease. Gastroenterology. 2008;134:568-576.

47. Henkel A, Green RM. The unfolded protein response in fatty liver disease. Semin Liver Dis. 2013;33:321-329.

48. Madan K, Bhardwaj P, Thareja S, Gupta SD, Saraya A. Oxidant stress and antioxidant status among patients with nonalcoholic fatty liver disease (NAFLD). J Clin Gastroenterol. 2006;40:930-935.

49. Yesilova Z, Ozata M, Oktenli C, et al. Increased acylation stimulating protein concentrations in nonalcoholic fatty liver disease are associated with insulin resistance. Am J Gastroenterol. 2005;100:842-849

50. Yesilova Z, Yaman H, Oktenli C, et al. Systemic markers of lipid peroxidation and antioxidants in patients with nonalcoholic Fatty liver disease. Am J Gastroenterol. 2005;100:850-855.

51. Lee JY, Zhao L, Youn HS, et al. Saturated fatty acid activates but polyunsaturated fatty acid inhibits Toll-like receptor 2 dimerized with Toll-like receptor 6 or 1. J Biol Chem. 2004;279:16971-16979.

52. Leszek J, Barreto GE, Gasiorowski K, Koutsouraki E, AvilaRodrigues M, Aliev G. Inflammatory mechanisms and oxidative stress as key factors responsible for progression of neurodegeneration: role of brain innate immune system. CNS Neurol Disord Drug Targets. 2016;15:329-336.

53. Shi H, Kokoeva MV, Inouye K, Tzameli I, Yin H, Flier JS. TLR4 links innate immunity and fatty acid-induced insulin resistance. J Clin Invest. 2006;116:3015-3025.

54. Hwang DH, Kim JA, Lee JY. Mechanisms for the activation of Tolllike receptor $2 / 4$ by saturated fatty acids and inhibition by docosahexaenoic acid. Eur J Pharmacol. 2016;785:24-35.

55. Pal D, Dasgupta S, Kundu R, et al. Fetuin-A acts as an endogenous ligand of TLR4 to promote lipid-induced insulin resistance. Nat Med. 2012;18:1279-1285.

56. Begin ME, Plourde M, Pifferi F, Cunnane SC. What is the link between docosahexaenoic acid, cognitive impairment, and Alzheimer's disease in the elderly? In: Montmayeur JP, le Coutre J, eds. Fat Detection: Taste, Texture, and Post Ingestive Effects. CRC Press/Taylor \& Francis: Boca Raton, FL; 2010.

57. Sandu RE, Buga AM, Uzoni A, Petcu EB, Popa-Wagner A. Neuroinflammation and comorbidities are frequently ignored factors in CNS pathology. Neural Regen Res. 2015;10:1349-1355.

58. Peters ME. Traumatic brain injury (TBI) in older adults: aging with a TBI versus incident TBI in the aged. Int Psychogeriatr. 2016;28:1931-1934.

59. Corrigan F, Mander KA, Leonard AV, Vink R. Neurogenic inflammation after traumatic brain injury and its potentiation of classical inflammation. J Neuroinflammation. 2016;13:264.

60. Lee JH, Wei ZZ, Cao W, et al. Regulation of therapeutic hypothermia on inflammatory cytokines, microglia polarization, migration and functional recovery after ischemic stroke in mice. Neurobiol Dis. 2016:96:248-260.

61. Fraser T, Tayler H, Love S. Low-temperature improved-throughput method for analysis of brain fatty acids and assessment of their post-mortem stability. J Neurosci Methods. 2008;169:135-140.

62. Nasaruddin ML, Holscher C, Kehoe P, Graham SF, Green BD. Wide-ranging alterations in the brain fatty acid complement of subjects with late Alzheimer's disease as detected by GC-MS. Am J Transl Res. 2016;8:154-165. 
63. Martins IV, Rivers-Auty J, Allan SM, Lawrence CB. Mitochondrial abnormalities and synaptic loss underlie memory deficits seen in mouse models of obesity and Alzheimer's disease. J Alzheimers Dis. 2017;55:915-932.

64. Karelina K, Sarac B, Freeman LM, Gaier KR, Weil ZM. Traumatic brain injury and obesity induce persistent central insulin resistance. Eur J Neurosci. 2016;43:1034-1043.

65. Taylor LE, Sullivan JC. Sex differences in obesity-induced hypertension and vascular dysfunction: a protective role for estrogen in adipose tissue inflammation? Am J Physiol Regul Integr Comp Physiol. 2016;311:R714-R720.

66. Alvarado-Garcia A, Hernandez-Quijano T, Hernandez-Valencia M, et al. Clinical practice guideline. Diagnosis and treatment of postmenopausal and perinemopausia. Rev Med Inst Mex Seguro Soc. 2015;53:214-225.

67. Han S, Zhao B, Pan X, et al. Estrogen receptor variant ER-alpha36 is involved in estrogen neuroprotection against oxidative toxicity. Neuroscience. 2015;310:224-241.

68. Cheng HY, Hung SH, Chu PJ. Rescue from sexually dimorphic neuronal cell death by estradiol and PI3 kinase activity. Cell Mol Neurobiol. 2016;36:767-775.

69. Sjogren LL, Morch LS, Lokkegaard E. Hormone replacement therapy and the risk of endometrial cancer: a systematic review. Maturitas. 2016;91:25-35.

70. Zarate A, Hernandez-Valencia M, Saucedo R, Basurto L, ManuelApolinar L. Current position about the use of estrogen therapy in women during the climacteric period. Rev Med Inst Mex Seguro Soc. 2014;52:66-69.

71. Farlow MR, Andreasen N, Riviere ME, et al. Long-term treatment with active Abeta immunotherapy with CAD106 in mild Alzheimer's disease. Alzheimers Res Ther. 2015;7:23

72. Miller AA, Spencer SJ. Obesity and neuroinflammation: a pathway to cognitive impairment. Brain Behav Immun. 2014;42:10-21.

73. Ferri CP, Prince M, Brayne C, et al. Global prevalence of dementia: a Delphi consensus study. Lancet. 2005;366:2112-2117.

74. Growdon ME, Schultz AP, Dagley AS, et al. Odor identification and Alzheimer disease biomarkers in clinically normal elderly. Neurology. 2015;84:2153-2160.

75. Lopategui Cabezas I, Herrera Batista A, Penton RG. The role of glial cells in Alzheimer disease: potential therapeutic implications. Neurologia. 2014;29:305-309.

76. Luterman JD, Haroutunian V, Yemul S, et al. Cytokine gene expression as a function of the clinical progression of Alzheimer disease dementia. Arch Neurol. 2000;57:1153-1160.

77. Eikelenboom P, van Gool WA. Neuroinflammatory perspectives on the two faces of Alzheimer's disease. J Neural Transm. 2004;111:281-294.

78. Lee JU, Kang DI, Zhu WL, Shin SY, Hahm KS, Kim Y. Solution structures and biological functions of the antimicrobial peptide, arenicin-1, and its linear derivative. Biopolymers. 2007;88:208-216.

79. Broe GA, Grayson DA, Creasey HM, et al. Anti-inflammatory drugs protect against Alzheimer disease at low doses. Arch Neurol. 2000;57:1586-1591.

80. Melton LM, Keith AB, Davis S, Oakley AE, Edwardson JA, Morris CM. Chronic glial activation, neurodegeneration, and APP immunoreactive deposits following acute administration of doublestranded RNA. Glia. 2003;44:1-12.

81. Wyss-Coray T, Yan F, Lin AH, et al. Prominent neurodegeneration and increased plaque formation in complement-inhibited Alzheimer's mice. Proc Natl Acad Sci USA. 2002;99:10837-10842.

82. Combs CK, Bates P, Karlo JC, Landreth GE. Regulation of beta-amyloid stimulated proinflammatory responses by peroxisome proliferator-activated receptor alpha. Neurochem Int. 2001;39:449-457.
83. Luth HJ, Munch G, Arendt T. Aberrant expression of NOS isoforms in Alzheimer's disease is structurally related to nitrotyrosine formation. Brain Res. 2002;953:135-143.

84. McGeer PL, Rogers J, McGeer EG. Inflammation, anti-inflammatory agents and Alzheimer disease: the last 12 years. J Alzheimers Dis. 2006;9(3 Suppl):271-276.

85. Bruce-Keller AJ, Keeling JL, Keller JN, Huang FF, Camondola S, Mattson MP. Antiinflammatory effects of estrogen on microglial activation. Endocrinology. 2000;141:3646-3656.

86. Wilms H, Zecca L, Rosenstiel P, Sievers J, Deuschl G, Lucius R. Inflammation in Parkinson's diseases and other neurodegenerative diseases: cause and therapeutic implications. Curr Pharm Des. 2007;13:1925-1928.

87. Dehay B, Bourdenx M, Gorry P, et al. Targeting alpha-synuclein for treatment of Parkinson's disease: mechanistic and therapeutic considerations. Lancet Neurol. 2015;14:855-866.

88. Anitua E, Pascual C, Perez-Gonzalez R, Orive G, Carro E. Intranasal PRGF-Endoret enhances neuronal survival and attenuates NFkappaB-dependent inflammation process in a mouse model of Parkinson's disease. J Control Release. 2015;203:170-180.

89. Teismann P, Schulz JB. Cellular pathology of Parkinson's disease: astrocytes, microglia and inflammation. Cell Tissue Res. 2004;318:149-161.

90. Wilms H, Rosenstiel P, Sievers J, Deuschl G, Zecca L, Lucius R. Activation of microglia by human neuromelanin is NF-kappaB dependent and involves p38 mitogen-activated protein kinase: implications for Parkinson's disease. FASEB J. 2003;17:500-502.

91. Zecca L, Wilms H, Geick S, et al. Human neuromelanin induces neuroinflammation and neurodegeneration in the rat substantia nigra: implications for Parkinson's disease. Acta Neuropathol. 2008;116:47-55

92. Korach KS. Insights from the study of animals lacking functional estrogen receptor. Science. 1994;266:1524-1527.

93. Windler E, Zyriax BC, Eidenmuller B, Boeing $\mathrm{H}$. Hormone replacement therapy and risk for coronary heart disease. Data from the CORA-study-a case-control study on women with incident coronary heart disease. Maturitas. 2007;57:239-246.

94. Castello-Porcar AM, Martinez-Jabaloyas JM. Testosterone/estradiol ratio, is it useful in the diagnosis of erectile dysfunction and low sexual desire? Aging Male. 2016;19:254-258.

95. Brzozowski AM, Pike AC, Dauter Z, et al. Molecular basis of agonism and antagonism in the oestrogen receptor. Nature. 1997;389:753-758.

96. Welsh AW, Lannin DR, Young GS, et al. Cytoplasmic estrogen receptor in breast cancer. Clin Cancer Res. 2012;18:118-126.

97. Htun H, Holth LT, Walker D, Davie JR, Hager GL. Direct visualization of the human estrogen receptor alpha reveals a role for ligand in the nuclear distribution of the receptor. Mol Biol Cell. 1999;10:471-486.

98. Govind AP, Thampan RV. Membrane associated estrogen receptors and related proteins: localization at the plasma membrane and the endoplasmic reticulum. Mol Cell Biochem. 2003;253:233-240.

99. Lieberman BA. The estrogen receptor activity cycle: dependence on multiple protein-protein interactions. Crit Rev Eukaryot Gene Expr. 1997;7:43-59.

100. Diep $\mathrm{CH}$, Ahrendt $\mathrm{H}$, Lange CA. Progesterone induces progesterone receptor gene (PGR) expression via rapid activation of protein kinase pathways required for cooperative estrogen receptor alpha $(E R)$ and progesterone receptor (PR) genomic action at ER/PR target genes. Steroids. 2016;114:48-58.

101. Borahay MA, Asoglu MR, Mas A, Adam S, Kilic GS, Al-Hendy A. Estrogen receptors and signaling in fibroids: role in pathobiology and therapeutic implications. Reprod Sci. 2017;24:1235-1244. 
102. Tabarestani S, Motallebi M, Akbari ME. Are estrogen receptor genomic aberrations predictive of hormone therapy response in breast cancer? Iran J Cancer Prev. 2016;9:e6565.

103. Szego CM, Davis JS. Adenosine $3^{\prime}, 5^{\prime}$-monophosphate in rat uterus: acute elevation by estrogen. Proc Natl Acad Sci USA. 1967;58:1711-1718.

104. Nakamura I, Kusakabe M, Swanson P, Young G. Regulation of sex steroid production and mRNAs encoding gonadotropin receptors and steroidogenic proteins by gonadotropins, cyclic AMP and insulin-like growth factor-I in ovarian follicles of rainbow trout (Oncorhynchus mykiss) at two stages of vitellogenesis. Comp Biochem Physiol A Mol Integr Physiol. 2016;201:132-140.

105. Audy MC, Vacher P, Duly B. 17 beta-estradiol stimulates a rapid $\mathrm{Ca}^{2+}$ influx in LNCaP human prostate cancer cells. Eur J Endocrinol. 1996;135:367-373.

106. Sharma G, Prossnitz ER. GPER/GPR30 knockout mice: effects of GPER on metabolism. Methods Mol Biol. 2016;1366:489-502.

107. Gaudet HM, Cheng SB, Christensen EM, Filardo EJ. The G-protein coupled estrogen receptor, GPER: the inside and inside-out story. Mol Cell Endocrinol. 2015;418:207-219.

108. Cheng SB, Graeber CT, Quinn JA, Filardo EJ. Retrograde transport of the transmembrane estrogen receptor, G-protein-coupled-receptor-30 (GPR30/GPER) from the plasma membrane towards the nucleus. Steroids. 2011;76:892-896.

109. Pupo M, Maggiolini M, Musti AM. GPER mediates non-genomic effects of estrogen. Methods Mol Biol. 2016;1366:471-488.

110. Prossnitz ER, Barton M. The G-protein-coupled estrogen receptor GPER in health and disease. Nat Rev Endocrinol. 2011;7:715-726.

111. Lei B, Peng W, Xu G, et al. Activation of G protein-coupled receptor 30 by thiodiphenol promotes proliferation of estrogen receptor alpha-positive breast cancer cells. Chemosphere. 2016;169:204-211.

112. Prossnitz ER, Barton M. Estrogen biology: new insights into GPER function and clinical opportunities. Mol Cell Endocrinol. 2014;389:71-83

113. Prossnitz ER, Arterburn JB. International union of basic and clinical pharmacology. XCVII. G protein-coupled estrogen receptor and its pharmacologic modulators. Pharmacol Rev. 2015;67:505-540.

114. Huang W, Chen Y, Liu Y, et al. Roles of ERbeta and GPR30 in proliferative response of human bladder cancer cell to estrogen. Biomed Res Int 2015;2015:251780.

115. Catalano S, Giordano C, Panza S, et al. Tamoxifen through GPER upregulates aromatase expression: a novel mechanism sustaining tamoxifen-resistant breast cancer cell growth. Breast Cancer Res Treat. 2014;146:273-285.

116. De Marinis E, Acaz-Fonseca E, Arevalo MA, et al. 17betaOestradiol anti-inflammatory effects in primary astrocytes require oestrogen receptor beta-mediated neuroglobin up-regulation. J Neuroendocrinol. 2013;25:260-270.

117. Pedersen AL, Brownrout JL, Saldanha CJ. Neuroinflammation and neurosteroidogenesis: reciprocal modulation during injury to the adult zebra finch brain. Physiol Behav. 2018;187:51-56.

118. Arevalo MA, Diz-Chaves Y, Santos-Galindo M, Bellini MJ, GarciaSegura LM. Selective oestrogen receptor modulators decrease the inflammatory response of glial cells. J Neuroendocrinol. 2012;24:183-190.

119. Baez-Jurado E, Rincon-Benavides MA, Hidalgo-Lanussa $O$ et al. Molecular mechanisms involved in the protective actions of selective estrogen receptor modulators in brain cells. Front Neuroendocrinol. 2019;52:44-64.

120. Vesga-Jimenez DJ, Hidalgo-Lanussa O, Baez-Jurado E, et al. Raloxifene attenuates oxidative stress and preserves mitochondrial function in astrocytic cells upon glucose deprivation. J Cell Physiol. 2019;234:2051-2057.
121. Straub RH. The complex role of estrogens in inflammation. Endocr Rev. 2007;28:521-574.

122. Rider V, Li X, Peterson G, Dawson J, Kimler BF, Abdou NI. Differential expression of estrogen receptors in women with systemic lupus erythematosus. J Rheumatol. 2006;33:1093-1101.

123. Cerciat M, Unkila M, Garcia-Segura LM, Arevalo MA. Selective estrogen receptor modulators decrease the production of interleukin- 6 and interferon-gamma-inducible protein-10 by astrocytes exposed to inflammatory challenge in vitro. Glia. 2010;58:93-102

124. Suzuki S, Brown CM, Wise PM. Neuroprotective effects of estrogens following ischemic stroke. Front Neuroendocrinol. 2009;30:201-211.

125. Barreto G, White RE, Ouyang Y, Xu L, Giffard RG. Astrocytes: targets for neuroprotection in stroke. Cent Nerv Syst Agents Med Chem. 2011;11:164-173.

126. Lanussa OH, Avila-Rodriguez M, Garcia-Segura LM, et al. Microglial dependent protective effects of neuroactive steroids. CNS Neurol Disord Drug Targets. 2016;15:242-249.

127. Choi SS, Lee HJ, Lim I, Satoh J, Kim SU. Human astrocytes: secretome profiles of cytokines and chemokines. PLoS ONE. 2014;9:e92325.

128. Liu CY, Yang Y, Ju WN, Wang X, Zhang HL. Emerging roles of astrocytes in neuro-vascular unit and the tripartite synapse with emphasis on reactive gliosis in the context of Alzheimer's disease. Front Cell Neurosci. 2018;12:193.

129. De LC, Colangelo AM, Alberghina L, Papa M. Neuro-immune hemostasis: homeostasis and diseases in the central nervous system. Front Cell Neurosci. 2018;12:459.

130. De Marinis E, Fiocchetti M, Acconcia F, Ascenzi P, Marino M. Neuroglobin upregulation induced by 17 beta-estradiol sequesters cytocrome $\mathrm{c}$ in the mitochondria preventing $\mathrm{H} 2 \mathrm{O} 2$-induced apoptosis of neuroblastoma cells. Cell Death Dis. 2013;4:4e508.

131. Azcoitia I, Arevalo MA, De Nicola AF, Garcia-Segura LM. Neuroprotective actions of estradiol revisited. Trends Endocrinol Metab. 2011:22:467-473.

132. Wang MJ, Huang HM, Chen HL, Kuo JS, Jeng KC. Dehydroepiandrosterone inhibits lipopolysaccharide-induced nitric oxide production in BV-2 microglia. J Neurochem. 2001;77:830-838.

133. Barger SW, Chavis JA, Drew PD. Dehydroepiandrosterone inhibits microglial nitric oxide production in a stimulus-specific manner. $J$ Neurosci Res. 2000;62:503-509.

134. Fujita H, Tanaka J, Toku K, et al. Effects of GM-CSF and ordinary supplements on the ramification of microglia in culture: a morphometrical study. Glia. 1996;18:269-281.

135. Ganter S, Northoff H, Mannel D, Gebicke-Harter PJ. Growth control of cultured microglia. J Neurosci Res. 1992;33:218-230.

136. Barreto G, Santos-Galindo M, Diz-Chaves Y, et al. Selective estrogen receptor modulators decrease reactive astrogliosis in the injured brain: effects of aging and prolonged depletion of ovarian hormones. Endocrinology. 2009;150:5010-5015.

137. Perry VH, Nicoll JA, Holmes C. Microglia in neurodegenerative disease. Nat Rev Neurol. 2010;6:193-201.

138. Schumacher M, Weill-Engerer S, Liere P, et al. Steroid hormones and neurosteroids in normal and pathological aging of the nervous system. Prog Neurobiol. 2003;71:3-29.

139. Tapia-Gonzalez S, Carrero P, Pernia O, Garcia-Segura LM, DizChaves Y. Selective oestrogen receptor (ER) modulators reduce microglia reactivity in vivo after peripheral inflammation: potential role of microglial ERs. J Endocrinol. 2008;198:219-230.

140. Barreto G, Veiga S, Azcoitia I, Garcia-Segura LM, GarciaOvejero D. Testosterone decreases reactive astroglia and reactive microglia after brain injury in male rats: role of its 
metabolites, oestradiol and dihydrotestosterone. Eur J Neurosci. 2007;25:3039-3046.

141. Stein DG. Progesterone exerts neuroprotective effects after brain injury. Brain Res Rev. 2008;57:386-397.

142. Garcia-Segura LM, Naftolin F, Hutchison JB, Azcoitia I, Chowen JA. Role of astroglia in estrogen regulation of synaptic plasticity and brain repair. J Neurobiol. 1999;40:574-584.

143. Petrone AB, Simpkins JW, Barr TL. 17beta-estradiol and inflammation: implications for ischemic stroke. Aging Dis. 2014;5:340-345.

144. Wu A, Shi Z, Martin S, Vincent A, Heilbronn L, Wittert G. Agerelated changes in estradiol and longitudinal associations with fat mass in men. PLoS ONE. 2018;13:e0201912.

145. Brown LM, Clegg DJ. Central effects of estradiol in the regulation of food intake, body weight, and adiposity. J Steroid Biochem Mol Biol. 2010;122:65-73.

146. Qian SW, Liu Y, Wang J, et al. BMP4 cross-talks with estrogen/ ERalpha signaling to regulate adiposity and glucose metabolism in females. EBioMedicine. 2016;11:91-100.

147. Engler-Chiurazzi EB, Brown CM, Povroznik JM, Simpkins JW. Estrogens as neuroprotectants: estrogenic actions in the context of cognitive aging and brain injury. Prog Neurobiol. 2017;157:188-211.

148. Yasrebi A, Rivera JA, Krumm EA, Yang JA, Roepke TA. Activation of estrogen response element-independent ERalpha signaling protects female mice from diet-induced obesity. Endocrinology. 2017;158:319-334.

149. Ponnusamy S, Tran QT, Harvey I, et al. Pharmacologic activation of estrogen receptor beta increases mitochondrial function, energy expenditure, and brown adipose tissue. FASEB J. 2017;31:266-281.

150. Shahed A, Simmons JJ, Featherstone SL, Young KA. Matrix metalloproteinase inhibition influences aspects of photoperiod stimulated ovarian recrudescence in Siberian hamsters. Gen Comp Endocrinol. 2015;216:46-53.

151. Wang ZF, Pan ZY, Xu CS, Li ZQ. Activation of G-protein coupled estrogen receptor 1 improves early-onset cognitive impairment via PI3K/Akt pathway in rats with traumatic brain injury. Biochem Biophys Res Commun. 2017;482:948-953.

152. Said MM, Bosland MC. The anti-inflammatory effect of montelukast, a cysteinyl leukotriene receptor-1 antagonist, against estradiol-induced nonbacterial inflammation in the rat prostate. Naunyn Schmiedebergs Arch Pharmacol. 2017;390:197-205.

153. Deshpande R, Khalili H, Pergolizzi RG, Michael SD, Chang MD. Estradiol down-regulates LPS-induced cytokine production and NFkB activation in murine macrophages. Am J Reprod Immunol. 1997;38:46-54.

154. Mak P, Li J, Samanta S, Mercurio AM. ERbeta regulation of NF$\mathrm{kB}$ activation in prostate cancer is mediated by HIF-1. Oncotarget. 2015;6:40247-40254.

155. Ascenzi P, di MA, Leboffe L, et al. Neuroglobin: from structure to function in health and disease. Mol Aspects Med. 2016;52:1-48.

156. Zhang LN, Hu SB, Deng SY, et al. Influences of DNA methylation upon neuroglobin sustained expression in oxygen- glucose deprivation model. Zhonghua Yi Xue Za Zhi. 2016;96:3164-3169.

157. Baez E, Echeverria V, Cabezas R, Avila-Rodriguez M, Garcia-Segura LM, Barreto GE. Protection by neuroglobin expression in brain pathologies. Front Neurol. 2016;7:146.

158. Fan R, Yu T, Lin JL, et al. Remote ischemic preconditioning improves post resuscitation cerebral function via overexpressing neuroglobin after cardiac arrest in rats. Brain Res. 2016;1648:345-355.

159. Amri F, Ghouili I, Amri M, Carrier A, Masmoudi-Kouki O. Neuroglobin protects astroglial cells from hydrogen peroxide-induced oxidative stress and apoptotic cell death. J Neurochem. 2017;140:151-169.

160. Toro-Urrego N, Garcia-Segura LM, Echeverria V, Barreto GE. Testosterone protects mitochondrial function and regulates neuroglobin expression in astrocytic cells exposed to glucose deprivation. Front Aging Neurosci. 2016;8:152.

161. Brunori M, Vallone B. Neuroglobin, seven years after. Cell Mol Life Sci. 2007;64:1259-1268.

162. De Marinis E, Ascenzi P, Pellegrini M, et al. 17beta-estradiol-a new modulator of neuroglobin levels in neurons: role in neuroprotection against $\mathrm{H}(2) \mathrm{O}(2)$-induced toxicity. Neurosignals. 2010;18:223-235.

163. Trent JT 3rd, Watts RA, Hargrove MS. Human neuroglobin, a hexacoordinate hemoglobin that reversibly binds oxygen. J Biol Chem. 2001;276:30106-30110

164. Yu ZL, Qiu S, Chen XC, et al. Neuroglobin - a potential biological marker of retinal damage induced by LED light. Neuroscience. 2014;270:158-167.

165. Hua S, Antao ST, Corbett A, Witting PK. The significance of neuroglobin in the brain. Curr Med Chem. 2010;17:160-172.

166. DellaValle B, Hempel C, Kurtzhals JA, Penkowa M. In vivo expression of neuroglobin in reactive astrocytes during neuropathology in murine models of traumatic brain injury, cerebral malaria, and autoimmune encephalitis. Glia. 2010;58:1220-1227.

167. Cabezas R, Baez-Jurado E, Hidalgo-Lanussa O, et al. Growth factors and neuroglobin in astrocyte protection against neurodegeneration and oxidative stress. Mol Neurobiol. 2019;56:2352.

168. Brittain T, Skommer J, Henty K, Birch N, Raychaudhuri S. A role for human neuroglobin in apoptosis. IUBMB Life. 2010;62:878-885.

169. Kloosterboer HJ. Tissue-selective effects of tibolone on the breast. Maturitas. 2004;49:S5-S15.

170. Reed MJ, Kloosterboer HJ. Tibolone: a selective tissue estrogenic activity regulator (STEAR). Maturitas. 2004;48(Suppl 1):S4-S6.

171. Steckelbroeck S, Jin Y, Oyesanmi B, Kloosterboer HJ, Penning TM. Tibolone is metabolized by the 3alpha/3beta-hydroxysteroid dehydrogenase activities of the four human isozymes of the aldo-keto reductase $1 \mathrm{C}$ subfamily: inversion of stereospecificity with a delta5(10)-3-ketosteroid. Mol Pharmacol. 2004;66:1702-1711.

172. Radowicki S, Arsoba J, Dubrawski W. Tibolone (Livial) in the treatment of disorders of the postmenopausal period (preliminary report). Ginekol Pol. 1988;59:705-708.

173. de Gooyer ME, Kleyn GT, Smits KC, Ederveen AG, Verheul HA, Kloosterboer HJ. Tibolone: a compound with tissue specific inhibitory effects on sulfatase. Mol Cell Endocrinol. 2001;183:55-62.

174. Colombo D, Ferraboschi P, Franchini L, Nishino H, Takayasu J, Tokuda $\mathrm{H}$. Anti-tumor-Promoting activity of tibolone and its metabolites. Arzneimittelforschung. 2008;58:86-90.

175. Carswell HV, Macrae IM, Gallagher L, Harrop E, Horsburgh KJ. Neuroprotection by a selective estrogen receptor beta agonist in a mouse model of global ischemia. Am J Physiol Heart Circ Physiol. 2004;287:H1501-H1504.

176. Tiwari-Woodruff S, Morales LB, Lee R, Voskuhl RR. Differential neuroprotective and antiinflammatory effects of estrogen receptor (ER)alpha and ERbeta ligand treatment. Proc Natl Acad Sci USA. 2007;104:14813-14818.

177. Spence RD, Voskuhl RR. Neuroprotective effects of estrogens and androgens in CNS inflammation and neurodegeneration. Front Neuroendocrinol. 2012;33:105-115.

178. Sinchak K, Mills RH, Tao L, LaPolt P, Lu JK, Micevych P. Estrogen induces de novo progesterone synthesis in astrocytes. Dev Neurosci. 2003;25:343-348

179. Herzog R, Zendedel A, Lammerding L, Beyer C, Slowik A. Impact of 17beta-estradiol and progesterone on inflammatory and apoptotic microRNA expression after ischemia in a rat model. J Steroid Biochem Mol Biol. 2017;167:126-134.

180. Yousuf S, Atif F, Sayeed I, Wang J, Stein DG. Neuroprotection by progesterone after transient cerebral ischemia in stroke-prone spontaneously hypertensive rats. Horm Behav. 2016;84:29-40. 
181. Ng YW, Say YH. Palmitic acid induces neurotoxicity and gliatoxicity in SH-SY5Y human neuroblastoma and T98G human glioblastoma cells. Peer J. 2018;6:e4696.

182. Crespo-Castrillo A, Yanguas-Casas N, Arevalo MA, Azcoitia I, Barreto GE, Garcia-Segura LM. The synthetic steroid tibolone decreases reactive gliosis and neuronal death in the cerebral cortex of female mice after a stab wound injury. Mol Neurobiol. 2018;55:8651-8667.

183. Morselli E, Fuente-Martin E, Finan B, et al. Hypothalamic PGC-1alpha protects against high-fat diet exposure by regulating ERalpha. Cell Rep. 2014;9:633-645.
How to cite this article: Hidalgo-Lanussa O, Baez-Jurado E, Echeverria V, et al. Lipotoxicity, neuroinflammation, glial cells and oestrogenic compounds. J Neuroendocrinol. 2020;32:e12776. https://doi.org/10.1111/jne.12776 